СТРАТЕШКО УНАПРЕЪЕЫЕ КВАЛИТЕТА ЗДРАВСТВЕНЕ ЗАШТИТЕ Драган Угринов ${ }^{1}$, Ана Гавриловић²

\title{
STRATEGIC QUALITY IMPROVEMENT OF HEALTH CARE
}

Dragan Ugrinov, Ana Gavrilovic

\section{Сажетак}

Стратегијом за унапређење квалитета здравствене заштите и безбедности пацијента тежи се достизағу највишег нивоа квалитета рада и безбедности пациијената у Републици Србији. Примена стратегије има опште и специфичне циивеве, и одговорност је свих субјеката друштва, а не само система здравствене заштите.

Кључне речи: Стратегија, ичиљ, квалитет здравтвене заштите, безбедност пацијената.

\section{Summary}

Strategy to improve health care quality and patient safety aims at achieving the highest level of quality of work and patient safety in the Republic of Serbia. Implementation of the strategy has the general and specific objectives, and the responsibility of all actors of society, not just the health care system.

Key words: Strategy, aim, zdravtvene quality of care, patient safety.

\footnotetext{
${ }^{1}$ Драган Угринов, дипл. ек. - мастер менаџмента у здравству, Завод за јавно здравље Панчево.

2 Доц. др Ана Гавриловић, Факултет за спорт, Ђорђа Станојевића 14, Београд.
} 
УВОД

\section{Дефиниција квалитета здравствене} заштите и безбедности пацијената

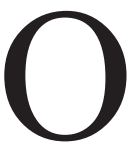
томе шта подразумевамо под квалитетом здравствених услуга или квалитетом здравствене заштите данас постоје различите „школе” и свака има сопствене термине и дефиниције. При томе, важно је истаћи, да свака професија, менаџери и други учесници, имају различите погледе на квалитет. Задатак лидера у области унапређења квалитета здравствене заштите је да обезбеде јединствено разумевање и сагласност између различитих учесника овог процеса око тога шта желе да постигну заједничким напорима. Дефиниција квалитета око које су се усагласили је полазна тачка за све.

Једна општеприхваћена дефиниција квалитета здравствене заштите, која се показала корисном у развоју и формулисању стратегија, независно од расположивих ресурса,истичедаје,„квалитетназдравствена заштита она која омогућава организацију ресурса на најделотворнији начин, како би се задовољиле здравствене потребе корисника за превенцијом и лечењем на безбедан начин, без непотребних губитака и на високом нивоу ьихових захтева". Ова дефиниција показује да је квалитет резултат начина на који се користе ресурси, а не тога колико их је на располагању. У наведеној дефиницији препозната је потреба за безбедном здравственом заштитом и поштовањем људских права. Таквом здравственом заштитом су обухваћена три основна полазишта за квалитет: корисници, односно пацијенти, здравствени радници и здравствени сарадници и менаџмент свеукупним квалитетом. Око дефинисања безбедности пацијента постоји сагласност да је то „идентификација, анализа и корекција ризичних догађаја са циљем да се здравствена заштита учини безбеднијом и да се ризици по здравље пацијента сведу на минимум”. При томе се препознаје да су нежељени догађаји кумулативни резултат бројних узрока, а ретко последица индивидуалних пропуста.

\section{Мисија квалитета}

Мисија сталног унапређења квалитета је да промовише значај безбедне и квалитетне здравствене заштите и омогући стварање услова за обуку здравствених радника и здравствених сарадника у здравственим установама, као и информисање јавности о значају и резултатима сталног унапређења квалитета у циљу очувања и унапређења здравља и бољег квалитета живота становника Републике Србије.

\section{Визија квалитета}

Визија сталног унапређења квалитета је достизање безбедне и сигурне здравствене заштите коју заједничким напорима развијају сви кључни актери у здравственом систему у интересу корисника. Здравствена заштита заснована је на најбољим доказима из праксе и истраживања, и у складу је са највишим професионалним и етичким стандардима.

\section{ПРИНЦИПИ И НАЧЕЛА УНАПРЕБЕЫА КВАЛИТЕТА ЗДРАВСТВЕНЕ ЗАШТИТЕ}

Закон о здравственој заштити из 2005. године, као једно од основних начела на којима је заснована здравствена заштита у Републици Србији, у члану 23 дефинише: „Начело сталног унапређења квалитета здравствене заштите остварује се мерама и активностима којима се у складу са савременим достигнућима медицинске науке и праксе повећавају могућности повољног исхода и смањивања ризика и других нежељених последица по здравље и здравствено стање појединца и заједнице у целини." Процес унапређења квалитета одвија се у више етапа и идентичан је са процесом који постоји у клиничкој пракси - дијагностикује се узрок лошег квалитета, а затим се тестирају интервенције које могу 
довести до његовог побољшања. Основне компоненте сталног унапређења квалитета у здравственој заштити су: усмереност на корисника, анализа процеса, развој тима за унапређење квалитета, једноставне методе које се користе на систематски начин да би се анализирали проблеми са квалитетом, примена плана, имплементација промена, прикупљање података, мониторинг и евалуација.

\section{Принципи квалитета здравствене заштите}

Стално унапређење квалитета здравствене заштите заснива се на вредностима које су уграђене у концепт квалитета рада и усвојене у свакодневној пракси здравствених установа:

- Усмереност на корисника - пацијента заштита која се пружа је креирана према специфичним потребама пацијента који је укључен у планирање, анализу и спровођење свог лечења. Ова здравствена заштита је договорена са пацијентом након што је он добио потпуне информације о свом здравственом стању.

- Безбедност - подразумева да се ради о стварању таквог система здравствене заштите у коме је безбедност пацијента примарна, а потенцијална опасност да се науди пацијенту током дијагностичких или терапијских процедура сведена је на најмању меру. У том систему се умањује опасност да се науди и онима који пружају здравствену заштиту. Овим су обухваћени како ризици из праксе, тако и они из окружења у коме се обезбеђује здравствена заштита.

- Делотворност - пружена здравствена заштита је одговарајућа за пацијента, а интервенција постиже жељени исход по здравље.

- Правовременост - здравствена заштита је пружена онда када је препозната потреба за њом, одговарајућа је и без непотребног чекања.
- Ефикасност - подразумева да се ресурси користе на начин и у окружењу који обезбеђују најбољу вредност за уложен новац, посебно када су у питању жељени исходи по здравље корисника.

- Правичност - подразумева да постоји једнак приступ услугама за све кориснике у стању здравствене потребе без обзира на разлике у полу, етничкој и верској припадности, инвалидитету, социјалноекономским карактеристикама и месту становања. За достизање и реализацију сваког принципа сталног унапређења квалитета потребно је дефинисање стандарда и показатеља за три основна аспекта здравствене заштите: структуре, процеса и исхода. Структура подразумева pecyрсе неопходне за обезбеђивање здравствене заштите, односно административне, организационе и технолошке могућности система да пружи квалитетну здравствену заштиту и задовољи потребе корисника. Овај аспект здравствене заштите обухвата карактеристике давалаца здравствених услуга и система здравствене заштите (број здравствених установа, њихову територијалну дистрибуцију, доступност, величину, опремљеност, број и структуру здравствених радника и здравствених сарадника, њихова знања и вештине, оптерећеност, мотивацију, финансирање). Процес здравствене заштите обухвата све активности које се предузимају од првог контакта корисника са системом здравствене заштите до решавања његовог проблема или задовољења потреба. То су: садржај и време пружања услуга, комуникација пацијента са здравственим радницима и здравственим сарадницима, благовремено информисање и укључивање пацијената у процес доношења одлука које се односе на његово здравље. Исход представља крајњи резултат примењеног процеса и односи се на побољшање здравственог стања појединаца, популационих група или цело- 
купног становништва након пружене здравственезаштите, као и на одговорност здравственог система на немедицинска очекивања корисника - задовољство пруженом здравственом заштитом. Унапређењем структуралних елемената побољшава се квалитет здравствене заштите до одређене границе. Мере процеса су критичне и најважније мере квалитета које непосредно одређују исход пружене здравствене заштите, док мере исхода зависе и од фактора на које систем здравствене заштите не може да утиче.

\section{Међународна искуства и препоруке}

Тежња да се обезбеди квалитетно лечење и брига о пацијенту, као и да се постигне најповољнији исход по здравље пацијента, стара је колико и лекарска професија. Међутим, организовани напори на процени и унапређењу квалитета рада у систему здравствене заштите новијег су датума. Међу онима који су дали значајан допринос у раној фази ове области истичу се Флоренс Најтингел, која је средином XIX века анализирала и публиковала извештај о великим разликама у исходу лечења у војним болницама; Ернест Кодман који се залагао за праћење и поређење резултата рада болница и учествовао у изради првог минималног стандарда за болнице у САД почетком XX века; Ли и Џонс који су 1933. годинепубликоваликапиталнодело,Основе добре медицинске праксе”. У области квалитета здравствене заштите, највећи допринос, крајем седамдесетих година прошлог века дао је Аведис Донабедиан са Харварда. Његова активност обухватила је систематизацију, категоризацију и критичку евалуацију сазнања у области процене и обезбеђења квалитета, како у теоријском, концептуалном делу, тако и у развоју инструмената за процену квалитета. Он је први увео поређење између пружене и очекиване здравствене заштите на основу дефинисаних стандарда као мерила. Затим је уследила и законска регулатива, прво у САД, где је 1972. године донет закон којим је уређено успостављање организације за развој професионалних стандарда и контролу квалитета у државним институцијама. У Европи су активности на обезбеђењу квалитета интензивиране после доношења програма Светске здравствене организације (СЗО) „Здравље за све” и формулисања специфичних циљева који се односе на унапређење квалитета. Од тада, активности и механизми за обезбеђење и унапређење квалитета постају све бројнији и разноврснији. Данас постоји широк спектар међународнихорганизацијакојеимајуутицај на развој и имплементацију регионалних, националних и међународних стратегија за унапређење квалитета здравствене заштите. Међу најутицајнијима су Заједнички комитет за акредитацију здравствених организација (JCAHO) и Институт за медицину (IOM) са седиштем у САД, као и Међународно друштво за обезбеђење 7 квалитета здравствене заштите (ISQua). У Европи лидери су Европско друштво за квалитет здравствене заштите (ESQH), Caвет Европе и Регионална канцеларија Светске здравствене организације за Европу. Савет Европе је основао Комитет експерата који је 1998. године, као оквир за упоређивање активности које се предузимају у различитим државама, дао предлог „Димензије система за побољшање квалитета". Исте године постигнута је сагласност о сарадњи на унапређењу квалитета здравствене заштите, а у мају 2000. године Европска унија (ЕУ) је усвојила нову здравствену политику која је узела у обзир препоруке о унапређењу квалитета здравствене заштите. Савет Европе је 2006. године усвојио основне препоруке о безбедности пацијената као меру квалитета здравствене заштите. Политика безбедности пацијената обухвата систем извештавања о ризицима по здравље пацијената, као и коришћење података о притужбама пацијената и захтевима за одштету. Ове препоруке такође обухватају и едукацију о безбедности пацијената уз стимулисање истраживања из ове области, као и сарадњу 
на националном и међународном нивоу. Европска комисија Европске уније тежиште ставља на примере добре праксе у домену сталног унапређења квалитета, јер они представљају најбоље доказе о безбедности, ефикасности и делотворности здравствене заштите и ефектима различитих приступа на унапређењу квалитета. Два главна циља иницијативе Европске комисије ЕУ из 2007. године су :

- да подржавају земље чланице у достизању највишег степена безбедности пацијената на тај начин што ће обезбедити релевантна практична и законска средства и механизме;

- да грађани ЕУ имају на располагању довољно релевантних информација о безбедности пацијената у здравственим системима ЕУ што ће повећати поверење грађана у ове системе.

\section{ЦИЉЕВИ СТРАТЕГИЈЕ $3 А$ УНАПРЕЪЕНЕ КВАЛИТЕТА ЗДРАВСТВЕНЕ ЗАШТИТЕ И БЕЗБЕДНОСТИ ПАЦИЈЕНАТА}

Примена стратегије има циљ да смањи:

- неуједначен квалитет здравствених услуга;

- неприхватљив ниво варирања у исходима по здравље лечених пацијената;

- неефикасно коришћење здравствених технологија;

- време чекања на медицинске процедуре и интервенције;

- незадовољство корисника пруженим здравственим услугама;

- незадовољство запослених у систему здравствене заштите;

- трошкове који настају због лошег квалитета.

Стално унапређење квалитета представља континуирани процес чији је циљ достизање вишег нивоа ефикасности и успешности у раду, као и веће задовољство корисника и давалаца здравствених услуга. Квалитет здравствене заштите мора се развијати и унапређивати континуирано имајући у виду следеће:

- Постоје варијације у пружању здравствене заштите и исходима по здравље за исте или сличне пацијенте, који добијају недовољну, као и непотребну или неадекватну здравствену заштиту. Разлике су присутне међу државама, регионима, здравственим установама и појединим даваоцима здравствених услуга, чак и тамо где су материјални, финансијски и хумани ресурси уједначени.

- Пружена здравствена заштита није увек безбедна као што би требало да буде, што безбедност пацијената сврстава у најважније димензије квалитетне здравствене заштите.

- Нова знања и технологије захтевају нове специјализације и субспецијализације здравствених радника и сарадника, што доводи до прекомерне фрагментације знања и праксе, и све веће отуђености од корисника у систему здравствене заштите. Последица тога је пораст незадовољства, како корисника тако и запослених у систему здравствене заштите.

- Захтеви корисника мењају се и постају све већи. Доступност модерних информационих технологија омогућава бољу информисаност корисника и доводи до већих очекивања у систему здравствене заштите. Савремени корисник очекује да добије такву здравствену заштиту у којој ће ризик по његово здравље бити минималан, а корист од пружене здравствене заштите максимална. Он се не задовољава само решавањем здравственог проблема, већ захтева и пријатан амбијент, љубазно особље, информисаност о стању свог здравља и медицинским процедурама којима ће бити подвргнут, односно постаје активни учесник у доношењу одлука о свом лечењу. 
- Трошкови здравствене заштите су у порасту, а често се за веома високу цену добијају сразмерно мали и ограничени ефекти по здравље становника. У таквим условима, захтева се већа ефикасност у систему здравствене заштите, односно да се за уложена средства обезбеди највећа добит по здравље људи.

- Интензивиран развој приватног сектора доводи до стварања здраве конкуренције у систему здравствене заштите. У таквим условима, установе које пружају квалитетну заштиту постају атрактивније, како за кориснике тако и за здравствене раднике. Стално унапређење квалитета захтева увођење културе квалитета која ће подједнако укључити све интересне групе - кориснике, даваоце здравствених услуга, финансијере и доносиоце одлука на свим нивоима. Традиционално схватање да су здравствени радници и здравствени сарадници, као непосредни даваоци здравствених услуга, једини одговорни за квалитет пружене здравствене заштите, замењено је новим приступом који препознаје значај организације у целини, а посебно улогу менаџмента, као и читавог процеса рада, а не појединачног извршења у задовољавању потреба корисника. Овај приступ усмерен је ка томе да утврди зашто се нешто дешава, а не ко је до тога довео, и да открије путеве који могу да превенирају лош квалитет. Предности увођења сталне културе квалитета могу се сагледати из неколико различитих перспектива. Из угла здравствене професије, увођење културе квалитета и сталног праћења квалитета рада води ка смањивању грешака из незнања, недостатка вештина, немара, недовољне мотивације, непажње. То је механизам за дефинисање нивоа разлика који је прихватљив за медицинску праксу, и начин да се оне сведу на минимум без угрожавања професионалне аутономије. Из перспективе корисника здравствене заштите, предности се огледају у омогућавању постизања адекватног одговора на његове захтеве и очекивања (минимални ризик по његово здравље уз максималну корист, као и добијање мерљивих резултата). Из перспективе финансирања здравствене заштите то је начин за унапређење ефикасности система здравствене заштите.

Стратегијом је дефинисано пет стратешких циљева које је требало остварити до 2015. године. Сваки од њих имао је своје специфичне циљеве, као и мере и активности за њихову реализацију.

\section{Први стратешки циљ}

1. Стварање услова да корисници/пацијенти буду у средишту система здравствене заштите.

\section{Специфични циљеви}

1.1. Препознавање и поштовање права пацијената у областима дефинисаним законом.

1.1.1. Обука запослених у систему здравствене заштите о правима пацијената.

1.1.2. Обука запослених у систему здравствене заштите за стицање вештина добре комуникације са корисницима/пацијентима.

1.1.3. Обука заштитника пацијентових права.

1.1.4. Увођење едукације о правима пацијента у наставне програме образовноваспитних установа и установа високог образовања здравствене струке.

1.1.5. Израда водича и процедура за поштовање права пацијената.

1.1.6. Кампање међу здравственим радницима о правима пацијената.

1.1.7. Кампање намењене подизању свести јавности о правима пацијента/корисника.

1.1.8. Праћење рада заштитника права пацијента у здравственој установи. 
1.2. Обезбеђивање учешћа корисника/пацијената у креирању здравствене политике и одлучивању о сопственом здрављу.

1.2.1. Подршка здравственим установама у формирању радних група задужених за комуникацију са удружењима пацијената.

1.2.2. Промовисање права на активно учешће корисника у креирању здравствене политике.

1.2.3. Национално истраживање и анализа резултата о задовољству корисника пруженим здравственим услугама.

1.2.4. Укључивање представника удружења пацијената/корисника и представника здравствених установа у рад здравствених одбора скупштина општина.

1.3. Побољшање доступности и приступачности здравствене заштите осетљивим популационим групама уз обезбеђивање стандарда квалитета.

1.3.1. Унапређење сарадње Министарства здравља са Министарством рада и социјалне политике у побољшању доступности и приступачности здравствене заштите посебно осетљивим популационим групама (особе са инвалидитетом, Роми, социјално угрожене особе и особе смештене у установама социјалне заштите).

1.3.2. Едукација и обука запослених у систему здравствене заштите о потребама посебно осетљивих популационих група, као и едукација о родној равноправности.

1.3.3. Идентификовање посебно осетљивих група у јединицама локалне самоуправе.

1.3.4. Процена потреба и израда локалних планова за побољшање доступности и приступачности здравствене заштите осетљивим популационим групама.

1.3.5. Стварање техничко-безбедних услова у здравственим установама за посебно осетљиве популационе групе, нарочито особе са инвалидитетом.

1.3.6. Израда процедура за пријем и безбедност осетљивих популационих група, посебно особа са инвалидитетом.

\section{Други стратешки циљ}

2. Унапређење стручног знања здравствених радника и подизање свести о значају сталног унапређења квалитета здравствене заштите и развијање специфичних знања и вештина.

\section{Специфични циљеви}

2.1. Едукација здравствених радника и здравствених сарадника.

2.1.1. Планска континуирана едукација здравствених радника и здравствених сарадника о сталном унапређењу квалитетаздравственезаштитеибезбедности пацијената као један од критеријума за релиценцирање здравствених радника.

2.1.2. Праћење и евалуација акредитованих програма континуиране едукације.

2.1.3. Израда планова стручног усавршавања здравствених радника и здравствених сарадника на нивоу здравствене установе.

2.1.4. Укључивање области сталног унапређења квалитета и безбедности пацијената у наставне програме додипломских и последипломских студија школа и факултета здравствене струке.

2.2 Развој и регулатива професионалних норми и стандарда који унапређују квалитет рада и безбедност пацијената.

2.2.1. Израда/ревизија протокола, водича и клиничких путева за унапређење квалитета и њихова имплементација.

2.2.2. Унапређење законске регулативе у области провере квалитета стручног рада здравствених радника и сарадника.

2.2.3. Израда показатеља за процену квалитета здравствене заштите који укључују стандарде и норме доброг квалитета. 
2.3. Стварање радних услова који стимулишу учење уз рад и усмерени су на унапређење квалитета и ефикасност рада и побољшање безбедности пацијената.

2.3.1. Национално истраживање, анализа и дисеминација резултата о професионалном задовољству у систему здравствене заштите.

2.3.2. Дефинисање процедуре за обуку новопримљених кадрова из сталног унапређења квалитета и безбедности пацијената у здравственој установи.

2.3.3. Изградња капацитета здравствених установа за „менаџмент свеукупним” (TQM) или развој другог модела менаџмента квалитетом, тамо где је то одговарајуће.

\section{Трећи стратешки циљ}

3. Стварање услова који промовишу културу сталног унапређења квалитета здравствене заштите и безбедност пацијената у здравственим установама.

\section{Специфични циљеви}

3.1. Унапређење система добровољне акредитације здравствених установа.

3.1.1. Унапређење стандарда за акредитацију на свим нивоима здравствене заштите.

3.1.2. Промовисање значаја акредитације здравствених установа путем медијских кампања.

3.1.3. Избор и едукација оцењивача за акредитацију.

3.1.4. Формирање тимова за самооцењивање у здравственим установама и њихова обука.

3.1.5. Именовање координатора за акредитацију из састава чланова Комисије за унапређење квалитета на нивоу здравствене установе и његова обука.

3.1.6. Израда и објављивање извештаја о обављеним акредитацијама здравствених установа на националном нивоу.
3.2 Управљање ризицима по здравље корисника/пацијената и запослених у здравственим установама.

3.2.1. Увођење менаџмента ризицима по здравље корисника/пацијената и запослених у здравственим установама.

3.2.2. Вођење евиденције нежељених догађаја.

3.2.3. Праћење и анализа нежељених догађаја и предузимање корективних мера на нивоу здравствене установе.

3.2.4. Формулисање процедура пријема, третмана и отпуста пацијента нарочито трудница и породиља.

3.2.5. Праћење и анализа професионалних обољења и предузимање превентивних мера на нивоу здравствене установе.

3.2.6. Израда плана за акцидентне ситуације на локалном нивоу и нивоу здравствене установе.

3.2.7. Израда плана очувања животне средине и руковања медицинским отпадом.

3.3. Праћење, унапређење и промовисање показатеља квалитета и учинка рада здравствених установа.

3.3.1. Израда плана унапређења квалитета здравствене заштите и безбедности пацијената на нивоу здравствене установе.

3.3.2. Увођење информационих и комуникационих технологија у здравствене установе ради унапређења и контроле квалитета података и показатеља квалитета рада.

3.3.3. Анализа мера извршења и унапређење учинка рада здравствених установа.

3.3.4. Праћење и унапређење показатеља квалитета здравствене заштите.

3.3.5. Формирање Републичке стручне комисије (РСК) за стално унапређење квалитета здравствене заштите и безбедност пацијената.

3.3.6 Рангирање здравствених установа на основу постигнутих резултата у сталном унапређењу квалитета заштите. 
3.4. Унапређење менаџмента листама чекања.

3.4.1. Ревизија критеријума за стављање пацијената на листу чекања.

3.4.2. Ревизија постојећих и утврђивање нових интервенција и процедура за стављање на листе чекања.

3.4.3. Редовно ажурирање и објављивање листа чекања на нивоу здравствене установе и националном нивоу.

3.4.4. Унапређење софтверског пакета за вођење листа чекања.

3.4.5. Медијске промоције и кампање намењене информисању јавности о листама чекања.

\section{Четврти стратешки циљ}

4. Обезбеђење сигурности, безбедности и исплативости здравствених технологија.

\section{Специфични циљеви}

4.1. Систематска процена расположивих доказа о новим и постојећим методама, процесима и техникама у здравственој заштити.

4.1.1. Ревизија законске регулативе у области здравствених технологија.

4.1.2. Израда упутства за процену постојећих и увођење нових здравствених технологија.

4.1.3. Процена постојећих и утврђивање потреба за увођењем нових технологија.

4.1.4. Одређивање приоритета за набавку медицинске опреме и инвестициона улагања у здравствене установе.

4.1.5. Увођење технолошки савремених и безбедносно сигурних информационих и комуникационих технологија у здравствене установе као компоненте интегрисаног здравственог система и подршке сталном унапређењу квалитета здравствене заштите.

4.2. Развој нових и ревизија постојећих водича добре праксе.
4.2.1. Израда упутства за израду водича добре праксе.

4.2.2. Ревизија постојећих и израда нових водича добре праксе.

4.2.3. Дисеминација, имплементација и евалуација водича добре праксе.

4.2.4. Едукација здравствених радника и здравствених сарадника за примену водича добре праксе.

4.3. Спровођење рационалне терапије лековима и рационално коришћење медицинских средстава.

4.3.1. Едукација здравствених радника и здравствених сарадника у циљу превенције нежељених реакција и интеракција лекова и грешака у медикацији.

4.3.2. Праћење и извештавање о нежељеним реакцијама лекова.

4.3.3. Формирање тимова у здравственим установама (лекар и фармацеут) за спровођење рационалне фармакотерапије.

4.3.4. Фармакоекономско праћење и истраживање терапијских програма.

\section{Пети стратешки циљ}

5. Обезбеђивање финансијских подстицаја за стално унапређење квалитета здравствене заштите и безбедности пацијената.

\section{Специфични циљеви}

5.1. Финансијски подстицаји здравственим установама за стално унапређење квалитета здравствене заштите.

5.1.1. Препознавање сталног унапређења квалитета здравствене заштите и увођење показатеља квалитета као критеријума за склапање уговора између Републичког завода за здравствено осигурање са здравственим установама.

5.1.2. Здравствене установе које су у поступку акредитације добиле сертификат о квалитету ће имати предност у закључивању уговора са матичном филијалом, односно Републичким заводом за здравствено осигурање. 
5.1.3. Опредељење средстава у буџету Министарства здравља за награђивање и подстицај најбољих здравствених установа, које су у плану мреже здравствених установа у постигнутим резултатима на сталном унапређењу квалитета здравствене заштите.

5.2. Финансијски подстицаји здравственим радницима и сарадницима.

5.2.1. Обезбедити механизме за стимулацију најбољих радника запослених у здравственој установи на сталном унапређењу квалитета на предлог Комисије за квалитет здравствене установе.

5.2.2. Опредељење финансијских средстава за континуирану едукацију здравствених радника и здравствених сарадника у здравственим установама.

5.2.3. Увођење критеријума сталног унапређења квалитета у нове начине плаћања давалаца здравствених услуга.

\section{ОДГОВОРНОСТ $3 А$}

\section{СПРОВОЂЕЫЕ СТАЛНОГ}

\section{УНАПРЕБЕЫА КВАЛИТЕТА}

ЗДРАВСТВЕНЕ ЗАШТИТЕ И

\section{БЕЗБЕДНОСТИ ПАЦИЈЕНАТА}

„Квалитет је посао свих” - слоган је који се у здравственом систему често користи и којим се наглашава да обавеза сталног унапређења квалитета није само обавеза појединаца, посебних комисија, односно здравствених установа, институција и др., већ треба да буде основа свеукупног пружања здравствене заштите корисницима/пацијентима. Да би квалитет био део свакодневног приступа при пружању здравствених услуга, неопходно је одредити јасне одговорности за спровођење иницијатива и активности на унапређењу квалитета и постизању задатих циљева.

1. Ниво доносиоца одлука.

Законом о здравственој заштити прописано је да је одговорност за креирање политике унапређења квалитета здравствене заштите у надлежности Здравственог савета Србије, Министарства здравља и осталих релевантних чинилаца, као што су:

- Етички одбор Србије;

- Републички завод за здравствено осигурање (Р33О);

- Институт за јавно здравље Србије „Др Милан Јовановић - Батут";

- Агенција за акредитацију здравствених установа Србије;

- Комисија за процену здравствених технологија;

- Републичке стручне комисије;

- Коморе здравствених радника;

- Комора здравствених установа.

\section{2. Ниво корисника услуга.}

Корисници услуга као појединци имају одговорност за стално унапређење квалитета здравствене заштите тако што ће препознати сопствене потребе и што hе учествовати у активностима на унапређењу квалитета, као што су истраживања задовољства корисника/пацијената и познавања њихових права и обавеза. Савремени корисник би требало да учествује у планирању и дефинисању здравствене заштите, процени рада здравствене службе, формирању јавног мњења, као и формирању партнерских односа са даваоцима здравствених услуга. Учешће корисника у планирању здравствене заштите води ка осећању одговорности и гарантује да ће у здравствену политику бити укључене потребе корисника, а истовремено обезбеђује мању зависност корисника у односу на даваоце здравствених услуга.

\section{3. Ниво давалаца услуга.}

На овом нивоу веома важну улогу имају здравствени радници и менаџери у здравственим установама који су одговорни за успостављање система и креирање културе сталног унапређења квалитета. Они анализирају сопствене услуге, предлажу и спроводе активности за унапређење квалитета пружених услуга, доносе план за 
унапређење квалитета стручног рада у здравственој установи, као и план стручног усавршавања здравствених радника и здравствених сарадника, спроводе испитивања задовољства корисника услуга и запослених у установи и на основу добијених резултата предузимају мере, доносе и реализују годишњи програм провере квалитета стручног рада у здравственој установи. У здравственим установама стручни органи који учествују у сталном унапређењу квалитета cy:

- стручни савет;

- стручни колегијум;

- етички одбор;

- комисија за унапређење квалитета рада.

4. Удружења.

Удружења корисника и давалаца здравствених услуга (Српско лекарско друштво, његове подружнице и секције, удружења пацијената, корисника здравствених услуга и грађана) значајна су за увођење културе

\section{ЛИТЕРАТУРА}

1. http://www.zdravlje.gov.rs/downloads/

Zakoni/Strategije/Strategija $\% 20$

Za\%20Stalno\%20Unapredjenje \%20

Kvaliteta $\% 20 Z$ dravstvene $\% 20 Z$ astite $\% 20$

I\%20Bezbednosti\%20Pacijenata.pdf, приступљено 14. 3. 2016.

2. Bleich, S.N., Ozaltin, E., Murray, C.K.L. How does satisfaction with the health-care system relate to patient experience?. Bulletin of the World Health Organization, 2009; 87(4): 271-8.

3. Volpp, K.G. Designing a model health care system. American Journal of Public Health, 2007; 97(12): 2126.

4. Khamlub S, Harun-Or-Rashid M, Sarker MA, Hirosawa T, Outavong P, Sakamoto J. Job satisfaction of health-care workers at health centers in Vientiane Capital and сталног унапређења квалитета. Они идентификују специфичне потребе појединих група корисника и давалаца здравствених услуга, проблеме у њиховом остваривању и предузимају иницијативе и активности за њихово решавање.

\section{ЗАКЈУУ}

Квалитет здравствене заштите је препознат као једна од најважнијих карактеристика система здравствене заштите, како државног тако и приватног сектора. Стално унапређење квалитета и безбедности пацијената је саставни део свакодневних активности здравствених радника, здравствених сарадника и свих других запослених у здравственом систему. Стално унапређење квалитета представља континуирани процес чији је циљ достизање вишег нивоа ефикасности и успешности у раду, као и веће задовољство корисника и давалаца здравствених услуга.

Bolikhamsai Province, Lao PDR. Nagoya J Med Sci 2013; 75: 233-41.

5. Станковић, Т., Квалитет процеса рада у примарној здравственој заштити. Институт за јавно здравље Србије „Др Милан Јовановић Батут“, Београд, 2006.

6. Угринов, Д., Стојанов, А. \& Симић, Л., Стратегијски менаџмент системом здравствене заштите - парадигма или потреба? Здравствена заштита, 2013; 42(6); 57-66.

7. Угринов Д., Гавриловић А., Марков М., Организационо функционисање примарне здравствене заштите.

Здравствена заштита, 2015; 44(4): 18-31.

8. ЗАКОН О ЗДРАВСТВЕНОЈ

ЗАШТИТИ. Сл. гласник РС 107/2005 и 72/2009 - др. закон.

9. ЗАКОН О ПРАВИМА ПАЦИЈЕНАТА. Службени гласник РС 45/13.

Контакт: Драган М. Угринов, дипл.ек. - мастер менаџмента у здравству, Завод за јавно здравље Панчево; e-mail: ugrinov.dragan@gmail.com 